\title{
THE CONTEXTUAL TEACHING AND LEARNING MODEL USAGE TO IMPROVE SCIENCE ATTITUDE IN SCIENCE'S LEARNING OF STUDENT CLASS V PUBLIC ELEMENTARY SCHOOL OF MANGKUBUMEN KULON NO. 38 SURAKARTA
}

\section{Ganing Widarwati, Peduk Rintayati, Chumdari}

Universitas Sebelas Maret ganingwidarwati@gmail.com

\section{Article History}

accepted 09/07/2018

approved 01/08/2018

published 17/09/2018

\section{Keywords}

contextual teaching and learning, learning IPA subject, science attitude

\begin{abstract}
The purpose of this research was to improve science attitude of student class $\mathrm{V}$ public elementary school of Mangkubumen Kulon No. 83 Surakarta through the Contextual Teaching and Learning (CTL) model usage in scirnce's learning. The kind of this research was Classroom Action Research. This research conducted until three cycle with each cycle consist of four stages, namely the planning stage, the stage of action implementation, the observation stage and the reflection stage. The data collection techniques were using interview technique, observation, and document review. The data validity techniques were using triangulation of data sources and triangulation of technique. The data analysis technique was interactive analysis technique which consist of four components, namely data provision, data reduction, data presentation, and data conclusion. The conclude of this research was the CTL model usage could improve the science attitude in science's learning of student class $\mathrm{V}$ public elementary school of Mangkubumen Kulon No. 83 Surakarta academic year 2017/2018.
\end{abstract}

Social, Humanities, and Education Studies (SHEs): Conference Series https://jurnal.uns.ac.id/shes
p-ISSN 2620-9284

e-ISSN 2620-9292 


\section{PENDAHULUAN}

IImu Pengetahuan Alam (IPA) meru-pakan salah satu mata pelajaran pokok dalam kurikulum pendidikan di Indonesia, ter-masuk pada jenjang sekolah dasar (Susanto, 2013). IPA memiliki tiga komponen yang saling terkait, yaitu IPA sebagai produk, proses, dan sikap. Hal ini didukung dengan Badan Standar Nasional Pendidikan (2006) bahwa IPA berhubungan dengan cara men-cari tahu tentang alam secara sistematis, se-hingga IPA bukan hanya penugasan kum-pulan pengetahuan yang berupa faktafakta, konsep-konsep, atau prinsip-prinsip saja me-lainkan juga merupakan suatu penemuan.

Pembelajaran di sekolah pada u-mumnya memperhatikan tiga kompetensi siswa sebagai tujuan pembelajaran yakni kognitif, afektif, dan psikomotorik. Pada pembelajaran IPA memiliki tiga komponen yang saling berhubungan dengan tiga kompetensi tersebut. IPA sebagai proses yang berhubungan tentang bagaimana menumbuhkan keterampilan-keterampilan pada diri siswa. IPA sebagai produk yang mendu-kung pada tercapainya tujuan kognitif atau pengetahuan. IPA sebagai sikap yang dapat menumbuhkan dan meningkatkan sikap sis-wa melalui kegiatan kealaman, baik penga-matan maupun eksperimen. Sikap di dalam pembelajaran IPA sering disebut sebagai sikap ilmiah. Sikap ilmiah adalah aspek ting-kah laku yang tidak dapat diajarkan melalui satuan pembelajaran tertentu, tetapi meru-pakan tingkah laku (behavior) yang "ditang-kap" melalui contoh-contoh positif yang ha-rus terus di dukung, dipupuk, dan dikem-bangkan sehingga dapat dimiliki oleh siswa (Bundu, 2006).

Berdasarkan hasil wawancara yang telah dilakukan pada tanggal $16 \quad-19$ Januari 2018 terhadap guru kelas V SD Negeri Mangkubumen Kulon No. 83 dan observasi pembelajaran IPA diperoleh gambaran bah-wa sikap ilmiah siswa kelas $\mathrm{V}$ masih perlu ditingkatkan. Hasil tersebut ditandai dengan beberapa hal sebagai berikut: 1) siswa cen-derung pasif dalam mengikuti pembelajaran IPA; 2) masih sedikit siswa yang antusias dalam pembelajaran; 3) masih sedikit siwa yang bertanya; 4) siswa belum bersungguh-sungguh dalam mengerjakan tugas, ditandai dengan munculnya keinginan mengerjakan tugas setelah mendapat perintah dari guru, dan 5) beberapa siswa kurang memperhati-kan penjelasan dari guru. Hal ini didukung dengan hasil observasi sikap ilmiah siswa yang telah dilaksanakan pada tanggal 19 Januari 2018 pada pembelajaran IPA kelas V SD Negeri Mangkubumen Kulon No. 83 yang diketahui bahwa sikap ilmiah siswa masih terbilang rendah dan perlu ditingkat-kan. Terdapat 4 siswa atau 22,22\% dengan kategori membudaya, 6 siswa atau 33,33\% dengan kategori mulai berkembang, 5 siswa atau 27,78\% dengan kategori mulai terlihat, dan 3 siswa atau $16,67 \%$ dengan kategori belum terlihat. Data tersebut berarti bahwa dari 18 siswa, terdapat 10 siswa atau $55,56 \%$ yang memiliki sikap ilmiah dengan kategori mulai berkembang $(B)$ maupun membudaya $(A)$.

Salah satu penyebab sikap ilmiah yang dimiliki siswa kelas V SD Negeri Mangkubumen Kulon No. 83 perlu ditingkat-kan adalah kualitas dari proses pembelajaran. Penerapan model pembelajaran di dalam kelas belum bervariasi. Guru telah berupaya menggunakan model kooperatif, namun belum dapat dimaksimalkan. Siswa belum dilibatkan secara langsung dalam pro-ses pembe-lajaran, baik dalam hal penemuan suatu pengetahuan, pengamatan, maupun percobaan. Kegiatan pengamatan atau percobaan terhadap fakta IPA hanya di-laksanakan oleh dua orang, sehingga mayo-ritas siswa kurang aktif dalam mengikuti pembelajaran. Padahal, sikap ilmiah dapat dikembangkan melalui kegiatan-kegiatan sis-wa dalam pembelajaran IPA saat melakukan diskusi, percobaan, simulasi, dan kegiatan proyek di lapangan (Susanto, 2013).

Kharmani menyatakan bahwa keber-hasilan siswa dalam mempelajari mata pela-jaran dipengaruhi oleh bagaimana sikap sis-wa terhadap mata pelajaran tersebut (Sama-towa, 2010). Hal ini menunjukkan bahwa sikap ilmiah pada pembelajaran IPA sangat berpengaruh terhadap ketercapaian tujuan pembelajaran. Siswa dengan sikap 
ilmiah rendah cenderung pasif dalam mengikuti pembelajaran, sehingga pengetahuan dan keterampilan yang dimilikinya terbatas pada penyampaian dari guru. Siswa sebaiknya mengkonstruksi pengetahuan yang dimiliki-nya dengan dilandasi sikap ilmiah, sehingga ia akan berusaha mencari tahu lebih dalam suatu pengetahuan yang belum dimilikinya. Upaya peningkatan sikap ilmiah siswa kelas V SD N Mangkubumen Kulon No. 83 telah dilakukan oleh guru kelas. Upaya tersebut meliputi penggunaan model kooperatif pada pembelajaran IPA dan memberikan motivasi serta nasehat. Penggunaan model kooperatif tersebut masih belum maksimal dilaksana-kan. Oleh karena itu, perlu adanya suatu ino-vasi pembelajaran yang lebih maksimal.

Alternatif solusi terhadap masalah rendahnya sikap ilmiah siswa adalah penggunaan model pembelajaran inovatif dengan kegiatan pengamatan maupun percobaan yang menyeluruh kepada siswa. Salah satu model pembelajaran yang dapat diterapkan adalah Contextual Teaching and Learning (CTL). Kegiatan pengamatan dan percobaan didukung dengan media pembelajaran yang menarik dan mengupayakan keseluruhan sis-wa dapat berpartisipasi.

Nurhadi menjelaskan bahwa Pembe-lajaran Kontekstual (Contextual Teaching and Learning) merupakan konsep belajar yang dapat membantu guru mengaitkan antara materi yang diajarkannya dengan situasi dunia nyata siswa dan mendorong siswa membuat hubungan antara pengeta-huan yang dimilikinya dengan penerapannya dalam kehidupan mereka sehari-hari. Kon-sep ini bertujuan agar hasil pembelajaran yang diperoleh dapat lebih bermakna bagi siswa karena proses pembelajaran dapat berlangsung secara alamiah dalam bentuk kegiatan siswa bekerja dan mengalami, bukan transfer pengetahuan dari guru ke siswa (Baharuddin dan Wahyuni, 2015)

Seorang ahli berpendapat bahwa pe-nerapan CTL dalam kelas cukup mudah di-laksanakan. Secara garis besar, Baharuddin dan Wahyuni (2015: 191-192) merinci lang-kah-langkah penerapan CTL di kelas adalah sebagai berikut: 1) Mengembangkan pemiki-ran bahwa anak akan belajar lebih bermakna dengan cara bekerja sendiri, menemukan sendiri, dan mengkonstruksi sendiri penge-tahuan dan keterampilan barunya; 2) Melak-sanakan sejauh mungkin kegiatan inquiry untuk semua topik; 3) Mengembangkan sifat ingin tahu siswa dengan bertanya; 3) Men-ciptakan "masyarakat belajar" (belajar dalam kelompok-kelompok); 4) Menghadirkan mo-del sebagai contoh pembelajaran; 5) Mela-kukan refleksi di akhir pertemuan, dan 6) Melakukan penilaian yang sebenarnya de-ngan berbagai cara.

\section{METODE}

Penelitian ini merupakan jenis pene-litian tindakan kelas yang dilaksanakan secara bersiklus. Penelitian tindakan kelas di-laksanakan di dalam kelas berupa tindakan nyata terhadap kegiatan belajar-mengajar untuk memperbaiki dan meningkatkan kondi-si pembelajaran (Iskandar, 2009). Penelitian ini dilaksanakan di SD Negeri Mangkubumen Kulon No. 83 Surakarta tahun ajaran 2017/ 2018. Subjek penelitian ini adalah guru kelas $\mathrm{V}$ dan siswa kelas $\mathrm{V}$ yang berjumlah 18 sis-wa terdiri dari 11 laki-laki dan 7 perempuan. Penelitian dilaksanakan selama tujuh bulan mulai dari Desember 2017 hingga Juni 2018.

Sumber data didapatkan dari hasil wawancara guru kelas $\mathrm{V}$ dan siswa, hasil observasi sikap ilmiah siswa, dan dokumen-tasi selama pembelajaran dan di luar pembelajaran. Teknik pengumpulan data dilaku-kan dengan teknik wawancara, observasi, dan dokumentasi. Uji validitas data menggu-nakan triagulasi sumber data dan triangulasi teknik. Analisis data yang digunakan adalah model analisis interaktif yang terdiri dari pengumpulan data, reduksi data, penyajian data, dan penarikan kesimpulan. 
HASIL DAN PEMBAHASAN

Berdasarkan hasil observasi sikap il-miah pratindakan diketahui bahwa siswa ke-las V SD Negeri Mangkubumen Kulon No. 83 Surakarta masih memiliki sikap ilmiah de-ngan kategori cukup. Skor rata-rata setiap aspek sikap ilmiah tertera pada Tabel 1 berikut:

Tabel 1. Skor Rata-rata Setiap Aspek Sikap Ilmiah Pratindakan

\begin{tabular}{lcc}
\multicolumn{1}{c}{ Aspek } & $\begin{array}{c}\text { Skor Rata- } \\
\text { rata }\end{array}$ & Kategori \\
\hline Kerja Keras & 9,94 & $\begin{array}{c}\text { Belum } \\
\text { Terlihat } \\
\text { Mulai } \\
\text { Disiplin }\end{array}$ \\
$\begin{array}{l}\text { Peduli Sosial } \\
\text { dan Lingkungan }\end{array}$ & 12,00 & $\begin{array}{c}\text { Berkembang } \\
\text { Mulai }\end{array}$ \\
$\begin{array}{l}\text { Jumlah Skor } \\
\text { Rata-rata }\end{array}$ & 35,05 & $\begin{array}{c}\text { Mulai } \\
\text { Berkembang }\end{array}$ \\
\hline
\end{tabular}

Berdasarkan pada Tabel 1 dapat di-ketahui bahwa aspek kerja keras dalam kategori belum terlihat, aspek disiplin serta pe-duli sosial dan lingkungan memiliki skor rata-rata dengan kategori mulai berkembang. Ha-sil tersebut terbukti bahwa sikap ilmiah ma-sih perlu ditingkatkan dan belum mencapai kategori mulai berkembang dan membudaya atau dengan skor $\geq 35$. Hasil observasi sikap ilmiah pratindakan dapat dibuat distribusi fre-kuensi sikap ilmiah pada Tabel 2 berikut:

Tabel 2. Distribusi Frekuensi Sikap IImiah Pratindakan

\begin{tabular}{|c|c|c|c|}
\hline \multirow[b]{2}{*}{ Skor } & \multirow{2}{*}{$\begin{array}{c}\text { Frekuensi } \\
\text { (Siswa) }\end{array}$} & \multicolumn{2}{|c|}{ Persentase (\%) } \\
\hline & & Relatif & Kumulatif \\
\hline 25 & 1 & 5,56 & 5,56 \\
\hline 28 & 2 & 5,56 & 11,12 \\
\hline 31 & 1 & 5,56 & 16,68 \\
\hline 33 & 3 & 11,10 & 27,78 \\
\hline 34 & 1 & 16,66 & 44,44 \\
\hline 35 & 1 & 5,56 & 50,00 \\
\hline 36 & 1 & 5,56 & 55,56 \\
\hline 37 & 3 & 16,66 & 72,22 \\
\hline 38 & 1 & 5,56 & 77,78 \\
\hline 40 & 2 & 5,56 & 83,34 \\
\hline 41 & 1 & 11,10 & 94,44 \\
\hline 45 & 1 & 5,56 & 100,00 \\
\hline Total & 18 & 100 & \\
\hline \multicolumn{4}{|c|}{$\begin{array}{l}\text { Nilai rata-rata kelas 35,05 (Mulai } \\
\text { Berkembang) } \\
\text { Persentase ketuntasan klasikal 55,56\% } \\
\text { Skor tertinggi } 45 \\
\text { Skor terendah } 25\end{array}$} \\
\hline
\end{tabular}

Berdasarkan pada Tabel 2, didapat-kan data mengenai sikap ilmiah siswa pratindakan yaitu dari 18 siswa 4 siswa atau 22,22\% dengan kategori membudaya, 6 siswa atau 33,33\% dengan kategori mulai berkembang, 5 siswa atau 27,78\% dengan kategori mulai terlihat, dan 3 siswa atau $16,67 \%$ dengan kategori belum terlihat. Sehingga klasifikasi kategori sikap ilmiah pratindakan pada Tabel 3 berikut: 
Tabel 3. Klasifikasi Kategori Sikap Ilmiah Pratindakan

\begin{tabular}{cccc}
$\begin{array}{c}\text { Interval } \\
\text { Skor }\end{array}$ & Kategori & $\begin{array}{c}f \\
\text { (Siswa) }\end{array}$ & $\begin{array}{c}\text { Persen- } \\
\text { tase }(\%)\end{array}$ \\
\hline $25-29$ & Belum Terlihat & 3 & 16,67 \\
$30-34$ & Mulai Terlihat & 5 & 27,78 \\
$35-39$ & Mulai Berkembang & 6 & 33,33 \\
$40-44$ & Membudaya & 4 & 22,22 \\
\hline & Jumlah & 18 & 100 \\
\hline
\end{tabular}

Data tersebut menandakan perlu adanya pelaksanaan tindakan pada siklus I. Pada siklus I dilaksanakan tindakan terha-dap siswa kelas V SD Negeri Mangkubumen Kulon No. 83 Surakarta berupa penggunaan model CTL pada pembelajaran IPA. Siklus I terdiri dari pertemuan 1 dan 2. Hasil obser-vasi sikap ilmiah siklus I pertemuan 1 dida-patkan skor rata-rata setiap aspek sikap ilmi-ah yang tertera pada Tabel 4 berikut:

Tabel 4. Skor Rata-rata Setiap Aspek Sikap IImiah Siklus I Pertemuan 1

\begin{tabular}{lcc}
\hline \multicolumn{1}{c}{ Aspek } & Skor Rata-rata & Kategori \\
\hline Kerja Keras & 4,83 & Mulai Berkembang \\
Disiplin & 5,44 & Mulai Berkembang \\
$\begin{array}{l}\text { Peduli Sosial } \\
\text { Peduli }\end{array}$ & 5,00 & Mulai Berkembang \\
Lingkungan & 6,00 & Mulai Berkembang \\
\hline $\begin{array}{l}\text { Jumlah Skor } \\
\text { Rata-rata }\end{array}$ & 21,27 & Mulai Berkembang \\
\hline
\end{tabular}

Berdasarkan pada Tabel 4 dapat di-ketahui bahwa keempat aspek sikap ilmiah yaitu kerja keras, disiplin, peduli sosial dan peduli lingkungan pada siklus I pertemuan 1 memiliki skor rata-rata dengan kategori mulai berkembang. Namun mengalami penurunan skor rata-rata. Hal ini terjadi karena adanya perbaikan instrumen pengamatan sikap ilmiah yang lebih terfokus pada empat aspek. Skor dengan kategori mulai berkembang maupun membudaya jika mencapai skor $\geq 21$. Selan-jutnya, hasil observasi sikap ilmiah siklus I pertemuan 1 dapat dibuat distribusi frekuensi sikap ilmiah pada Tabel 5 berikut:

Tabel 5. Distribusi Frekuensi Sikap IImiah Siklus I Pertemuan 1

\begin{tabular}{|c|c|c|c|}
\hline \multirow[b]{2}{*}{ Skor } & \multirow{2}{*}{$\begin{array}{c}\text { Frekuensi } \\
\text { (Siswa) }\end{array}$} & \multicolumn{2}{|c|}{ Persentase (\%) } \\
\hline & & Relatif & Kumulatif \\
\hline 15 & 1 & 5,56 & 5,56 \\
\hline 17 & 1 & 5,55 & 11,11 \\
\hline 18 & 1 & 5,55 & 16,66 \\
\hline 19 & 4 & 22,22 & 38,88 \\
\hline 20 & 1 & 5,56 & 44,44 \\
\hline 21 & 1 & 5,56 & 50,00 \\
\hline 23 & 3 & 16,66 & 66,66 \\
\hline 24 & 4 & 22,22 & 88,88 \\
\hline 25 & 1 & 5,56 & 94,44 \\
\hline 26 & 1 & 5,56 & 100,00 \\
\hline Total & 18 & 100 & \\
\hline \multicolumn{4}{|c|}{$\begin{array}{l}\text { Nilai rata-rata kelas 21,07 (Mulai } \\
\text { Berkembang) } \\
\text { Persentase ketuntasan klasikal 55,56\% } \\
\text { Skor tertinggi } 26 \\
\text { Skor terendah } 15\end{array}$} \\
\hline
\end{tabular}


Berdasarkan pada Tabel 5 di atas di-dapatkan data mengenai sikap ilmiah siswa siklus I pertemuan 1 yaitu dari 18 siswa, 6 siswa atau 33,33\% dalam kategori membudaya, 4 siswa atau 22,22\% dalam kategori mulai berkembang, 6 siswa atau $33,34 \%$ dalam kategori mulai terlihat, dan 2 siswa atau 11,11\% dalam kategori belum terlihat. Sehingga dapat dibuat klasifikasi kategori sikap ilmiah siklus I pertemuan 1 pada Tabel 6 berikut:

Tabel 6. Klasifikasi Kategori Sikap IImiah Siklus I Pertemuan 1

\begin{tabular}{cccc}
\hline $\begin{array}{c}\text { Interval } \\
\text { Skor }\end{array}$ & Kategori & $\begin{array}{c}f \\
\text { (Siswa) }\end{array}$ & $\begin{array}{c}\text { Persen- } \\
\text { tase }(\%)\end{array}$ \\
\hline $15-17$ & Belum Terlihat & 2 & 11,11 \\
$18-20$ & Mulai Terlihat & 6 & 33,34 \\
$21-23$ & Mulai Berkembang & 4 & 22,22 \\
$24-26$ & Membudaya & 6 & 33,33 \\
\hline & Jumlah & 18 & 100 \\
\hline
\end{tabular}

Data sikap ilmiah siklus I pertemuan 1 menunjukkan belum mencapai indikator kinerja penelitian ini. Kemudian data hasil observasi sikap ilmiah siklus I pertemuan 2 didapatkan skor rata-rata setiap aspek sikap ilmiah yang tertera pada Tabel 7 sebagai berikut:

Tabel 7. Skor Rata-rata Setiap Aspek Sikap IImiah Siklus I Pertemuan 2

\begin{tabular}{|c|c|c|}
\hline Aspek & Skor Rata-rata & Kategori \\
\hline Kerja Keras & 5,94 & $\begin{array}{c}\text { Mulai } \\
\text { Berkembang }\end{array}$ \\
\hline Disiplin & 5,44 & $\begin{array}{c}\text { Mulai } \\
\text { Berkembang }\end{array}$ \\
\hline Peduli Sosial & 6,44 & Membudaya \\
\hline $\begin{array}{l}\text { Peduli } \\
\text { Lingkungan }\end{array}$ & 5,67 & $\begin{array}{c}\text { Mulai } \\
\text { Berkembang }\end{array}$ \\
\hline $\begin{array}{l}\text { Jumlah Skor } \\
\text { Rata-rata }\end{array}$ & 23,49 & $\begin{array}{c}\text { Mulai } \\
\text { Berkembang }\end{array}$ \\
\hline
\end{tabular}

Berdasarkan pada Tabel 5 dapat di-ketahui bahwa tiga dari empat aspek sikap ilmiah pada siklus I pertemuan 2 yaitu kerja keras, disiplin, dan peduli lingkungan memiliki skor rata-rata dengan kategori mulai berkembang dan satu aspek lainnya yaitu peduli sosial dalam kategori membudaya. Skor dengan kategori mulai berkembang maupun membudaya jika mencapai skor $\geq 23$. Selanjutnya, hasil observasi sikap ilmiah siklus I pertemuan 2 dapat dibuat dis-tribusi frekuensi sikap ilmiah siklus I per-temuan 2 pada Tabel 8 sebagai berikut ini:

Tabel 8. Distribusi Frekuensi Sikap IImiah Siklus I Pertemuan 2

\begin{tabular}{|c|c|c|c|}
\hline \multirow[b]{2}{*}{ Skor } & \multirow{2}{*}{$\begin{array}{c}\text { Frekuensi } \\
\text { (Siswa) }\end{array}$} & \multicolumn{2}{|c|}{ Persentase (\%) } \\
\hline & & Relatif & Kumulatif \\
\hline 19 & 1 & 5,56 & 5,56 \\
\hline 21 & 1 & 5,56 & 11,12 \\
\hline 22 & 4 & 22,22 & 33,34 \\
\hline 24 & 7 & 38,88 & 72,22 \\
\hline 25 & 4 & 22,22 & 94,44 \\
\hline 27 & 1 & 5,56 & 100,00 \\
\hline Total & 18 & 100 & \\
\hline \multicolumn{4}{|c|}{$\begin{array}{l}\text { Nilai rata-rata kelas 23,50 (Mulai } \\
\text { Berkembang) } \\
\text { Persentase ketuntasan klasikal 66,67\% } \\
\text { Skor tertinggi } 27 \\
\text { Skor terendah } 19\end{array}$} \\
\hline
\end{tabular}


Berdasarkan pada Tabel 8 dida-patkan data mengenai sikap ilmiah siswa siklus I pertemuan 2 yaitu dari 18 siswa, 5 siswa atau $27,78 \%$ dalam kategori membu-daya, 7 siswa atau 38,89\% dalam kategori mulai berkembang, 5 siswa atau 27,78\% da-lam kategori mulai terlihat, dan 1 siswa atau 5,55\% dalam kategori belum terlihat. Sehingga dapat dibuat klasifikasi kategori sikap il-miah siklus I pertemuan 2 pada Tabel 9 berikut:

Tabel 9. Klasifikasi Kategori Sikap IImiah Siklus I Pertemuan 2

\begin{tabular}{|c|c|c|c|}
\hline $\begin{array}{c}\text { Interval } \\
\text { Skor }\end{array}$ & Kategori & $\begin{array}{c}f \\
\text { (Siswa) }\end{array}$ & $\begin{array}{l}\text { Persen- } \\
\text { tase (\%) }\end{array}$ \\
\hline $19-20$ & Belum Terlihat & 1 & 11,11 \\
\hline $21-22$ & Mulai Terlihat & 5 & 33,34 \\
\hline $23-24$ & Mulai Berkembang & 7 & 22,22 \\
\hline $25-26$ & Membudaya & 5 & 33,33 \\
\hline & Jumlah & 18 & 100 \\
\hline
\end{tabular}

Data sikap ilmiah hingga siklus I per-temuan 2 menunjukkan belum mencapai in-dikator kinerja penelitian ini. Pelaksanaan tindakan pada siklus I pertemuan 1 hingga pertemuan 2 menghasilkan data yang me-nunjukkan indikator kinerja penelitian yang ditetapkan sebesar $\geq 80 \%$ siswa memiliki sikap ilmiah dengan kategori mulai berkembang maupun membudaya belum tercapai dikarenakan beberapa kendala. Kendala ter-sebut diantaranya adalah: 1) model CTL ba-ru diperkenalkan oleh guru kepada siswa; 2) guru belum menguasai tahapan-tahapan model CTL berdasarkan komponennya; 3) materi yang disampaikan tidak mudah dikons-truksikan dengan pengetahuan siswa dalam kehidupan sehari-hari, dan 4) siswa kurang antusias dalam pembelajaran dikare-nakan hanya berupa kegiatan pengamatan. Kendala-kendala tersebut harus diminimal-kan dan diperbaiki agar pembelajaran dapat berlangsung dengan baik dan maksimal. Oleh karena itu, penelitian dilanjutkan pada tindakan siklus II dengan harapan dapat meningkatkan sikap ilmiah siswa yang sudah terbentuk. Hasil observasi sikap ilmiah siklus II pertemuan 1 didapatkan skor rata-rata setiap aspek pada Tabel 10 berikut:

Tabel 10. Skor Rata-rata Setiap Aspek Sikap IImiah Siklus II Pertemuan 1

\begin{tabular}{lcc}
\hline \multicolumn{1}{c}{ Aspek } & Skor Rata-rata & Kategori \\
\hline Kerja Keras & 6,05 & $\begin{array}{c}\text { Mulai } \\
\text { Berkembang } \\
\text { Mulai }\end{array}$ \\
Disiplin & 5,56 & $\begin{array}{c}\text { Berkembang } \\
\text { Membudaya } \\
\text { Mulai }\end{array}$ \\
$\begin{array}{l}\text { Peduli Sosial } \\
\text { Peduli }\end{array}$ & 6,44 & Berkembang \\
Lingkungan & 5,89 & Mulai Terlihat \\
\hline $\begin{array}{l}\text { Jumlah Skor } \\
\text { Rtaa-rata }\end{array}$ & 23,94 &
\end{tabular}

Berdasarkan pada Tabel 10 dapat di-ketahui bahwa tiga dari empat aspek sikap ilmiah pada siklus II pertemuan 1 yaitu kerja keras, disiplin dan peduli lingkungan memiliki skor rata-rata dengan kategori mulai ber-kembang dan aspek lainnya yaitu peduli so-sial dalam kategori membudaya. Skor mulai berkembang maupun membudaya $\geq 24$. Selanjutnya didapatkan data mengenai sikap ilmiah siswa siklus II pertemuan 1 yaitu dari 18 siswa, 5 siswa atau 27,78\% dalam kategori membudaya, 3 siswa atau $16,67 \%$ dalam kategori mulai berkembang, 9 siswa atau $50 \%$ dalam kategori mulai terlihat, dan masih terdapat 1 siswa atau 5,55\% dalam kategori belum terlihat. Data hasil observasi sikap ilmiah siklus II pertemuan 1 dapat dibuat distribusi frekuensi sikap ilmiah siklus II pertemuan 2 yang tertera pada Tabel 11 sebagai berikut: 
Tabel 11. Distribusi Frekuensi Sikap IImiah Siklus II Pertemuan 1

\begin{tabular}{|c|c|c|c|}
\hline \multirow[b]{2}{*}{ Skor } & \multirow{2}{*}{$\begin{array}{c}\text { Frekuensi } \\
\text { (Siswa) }\end{array}$} & \multicolumn{2}{|c|}{ Persentase (\%) } \\
\hline & & Relatif & Kumulatif \\
\hline 23 & 1 & 5,56 & 5,56 \\
\hline 25 & 2 & 11,11 & 16,67 \\
\hline 26 & 1 & 5,56 & 22,23 \\
\hline 27 & 1 & 5,56 & 27,79 \\
\hline 28 & 4 & 22,21 & 50,00 \\
\hline 29 & 2 & 11,11 & 61,11 \\
\hline 30 & 1 & 5,56 & 66,67 \\
\hline 31 & 1 & 5,56 & 72,23 \\
\hline 32 & 2 & 11,11 & 83,34 \\
\hline 33 & 2 & 11,11 & 94,45 \\
\hline 36 & 1 & 5,55 & 100,00 \\
\hline Total & 18 & 100 & \\
\hline \multicolumn{4}{|c|}{$\begin{array}{l}\text { Nilai rata-rata kelas 29,05 (Mulai } \\
\text { Berkembang) } \\
\text { Persentase ketuntasan klasikal 50,00\% } \\
\text { Skor tertinggi } 36 \\
\text { Skor terendah } 23\end{array}$} \\
\hline
\end{tabular}

Berdasarkan pada Tabel 11 di atas dapat dibuat klasifikasi kategori sikap ilmiah siklus II pertemuan 1 pada Tabel 12 berikut:

Tabel 12. Klasifikasi Kategori Sikap IImiah Siklus II Pertemuan 1

\begin{tabular}{cccc}
\hline & Frekuensi & \multicolumn{2}{c}{ Persentase (\%) } \\
\cline { 3 - 4 } Skor & (Siswa) & Relatif & Kumulatif \\
\hline 18 & 1 & 5,56 & 5,56 \\
21 & 2 & 11,10 & 16,66 \\
22 & 5 & 27,80 & 44,46 \\
23 & 2 & 11,10 & 55,56 \\
24 & 1 & 5,56 & 61,12 \\
25 & 2 & 11,10 & 72,22 \\
27 & 2 & 11,10 & 83,32 \\
28 & 1 & 5,56 & 88,88 \\
29 & 1 & 5,56 & 94,44 \\
30 & 1 & 5,56 & 100,00 \\
\hline Total & 18 & 100 & \\
\hline Nilai rata-rata kelas 23,94 (Mula Terlihat) \\
Persentase ketuntasan klasikal 44,44\% \\
Skor tertinggi 30 \\
Skor terendah 18
\end{tabular}

Data sikap ilmiah siklus II pertemuan 1 menunjukkan belum mencapai indikator kinerja penelitian ini. Kemudian data hasil observasi sikap ilmiah siklus II pertemuan 2 didapatkan skor rata-rata setiap aspek sikap ilmiah yang tertera pada Tabel 13 berikut:

Tabel 13. Skor Rata-rata Setiap Aspek Sikap IImiah Siklus II Pertemuan 2

\begin{tabular}{lcc}
\hline \multicolumn{1}{c}{ Aspek } & Skor Rata-rata & Kategori \\
\hline Kerja Keras & 6,66 & $\begin{array}{c}\text { Mulai } \\
\text { Berkembang } \\
\text { Disiplin }\end{array}$ \\
$\begin{array}{l}\text { Mulai Terlihat } \\
\text { Peduli Sosial }\end{array}$ & 7,17 & $\begin{array}{c}\text { Mulai } \\
\text { Berkembang }\end{array}$ \\
$\begin{array}{l}\text { Peduli } \\
\text { Lingkungan }\end{array}$ & 7,72 & Membudaya \\
$\begin{array}{l}\text { Jumlah Skor } \\
\text { Rata-rata }\end{array}$ & 29,05 & $\begin{array}{c}\text { Mulai } \\
\text { Berkembang }\end{array}$ \\
\hline
\end{tabular}


Berdasarkan pada Tabel 13 dapat di-ketahui bahwa aspek kerja keras dan peduli sosial memiliki skor rata-rata dengan ka-tegori mulai berke-bang, Aspek disiplin da-lam kategori mulai terlihat, dan aspek peduli lingkungan dalam kategori membudaya. Skor dengan kategori mulai berkembang maupun membudaya jika mencapai skor $\geq 29$. Selanjutnya, hasil observasi sikap ilmiah siklus II pertemuan 2 dapat dibuat distribusi frekuensi sikap ilmiah siklus II pertemuan 2 pada Tabel 14 sebagai berikut ini:

Tabel 14. Distribusi Frekuensi Sikap IImiah Siklus II Pertemuan 2

\begin{tabular}{|c|c|c|c|}
\hline \multirow[b]{2}{*}{ Skor } & \multirow{2}{*}{$\begin{array}{l}\text { Frekuensi } \\
\text { (Siswa) }\end{array}$} & \multicolumn{2}{|c|}{ Persentase (\%) } \\
\hline & & Relatif & Kumulatif \\
\hline 23 & 1 & 5,56 & 5,56 \\
\hline 25 & 2 & 11,11 & 16,67 \\
\hline 26 & 1 & 5,56 & 22,23 \\
\hline 27 & 1 & 5,56 & 27,79 \\
\hline 28 & 4 & 22,21 & 50,00 \\
\hline 29 & 2 & 11,11 & 61,11 \\
\hline 30 & 1 & 5,56 & 66,67 \\
\hline 31 & 1 & 5,56 & 72,23 \\
\hline 32 & 2 & 11,11 & 83,34 \\
\hline 33 & 2 & 11,11 & 94,45 \\
\hline 36 & 1 & 5,55 & 100,00 \\
\hline Total & 18 & 100 & \\
\hline \multicolumn{4}{|c|}{$\begin{array}{l}\text { Nilai rata-rata kelas 29,05 (Mulai } \\
\text { Berkembang) } \\
\text { Persentase ketuntasan klasikal 50,00\% } \\
\text { Skor tertinggi } 36 \\
\text { Skor terendah } 23\end{array}$} \\
\hline
\end{tabular}

Berdasarkan pada Tabel 14 data mengenai sikap ilmiah siswa siklus II pertemuan 2 yaitu dari 18 siswa, 5 siswa atau 27,78\% dalam kategori membudaya, 4 siswa atau $22,22 \%$ dalam kategori mulai berkembang, 6 siswa atau 33,33\% dalam kategori mulai terlihat, dan 3 siswa atau $16,67 \%$ dalam kategori belum terlihat. Sehingga klasifikasi kategori sikap ilmiah siklus II pertemuan 2 pada Tabel 15 berikut:

Tabel 15. Klasifikasi Kategori Sikap IImiah Siklus II Pertemuan 2

\begin{tabular}{cccc}
\hline $\begin{array}{c}\text { Interval } \\
\text { Skor }\end{array}$ & Kategori & $\begin{array}{c}f \\
\text { (Siswa) }\end{array}$ & $\begin{array}{c}\text { Persen- } \\
\text { tase }(\%)\end{array}$ \\
\hline $23-25$ & Belum Terlihat & 3 & 16,67 \\
$26-28$ & Mulai Terlihat & 6 & 33,33 \\
$29-31$ & Mulai Berkembang & 4 & 22,22 \\
$32-34$ & Membudaya & 5 & 27,78 \\
\hline & Jumlah & 18 & 100 \\
\hline
\end{tabular}

Pelaksanaan tindakan pada siklus II pertemuan 1 hingga pertemuan 2 menghasilkan data yang menunjukkan indikator kinerja penelitian yang ditetapkan sebesar $\geq 80 \%$ siswa memiliki sikap ilmiah dengan kategori membudaya belum tercapai karena beberapa kendala yang masih ada. Kendala tersebut diantaranya adalah: 1) model CTL mulai dikuasai guru namun belum maksimal, 2) masih terdapat siswa yang kurang antu-sias dalam pembelajaran dikarenakan memi-liki karakter pendiam. Kendalakendala ter-sebut harus diminimalkan dan diperbaiki agar pembelajaran dapat berlangsung de-ngan baik dan maksimal ke seluruh siswa.. Hal ini menjadi motivasi guru untuk memper-baiki lagi kekurangan yang terjadi. Oleh ka-rena itu, penelitian 
dilanjutkan pada tindakan siklus III dengan harapan dapat mening-katkan sikap ilmiah siswa dan mencapai indi-kator kinerja penelitian yang telah diten-tukan. Hasil observasi sikap ilmiah siklus III pertemuan 1 didapatkan skor rata-rata setiap aspek sikap ilmiah pada Tabel 16 berikut:

\begin{tabular}{llcc} 
Tabel 16. Skor & Rata-rata Setiap Aspek Sikap IImiah Siklus III Pertemuan 1 \\
\cline { 2 - 4 } \multicolumn{2}{c}{ Aspek } & $\begin{array}{c}\text { Skor } \\
\text { Rata-rata }\end{array}$ & Kategori \\
\cline { 2 - 4 } & Kerja Keras & 8,17 & Mulai Berkembang \\
& Disiplin & 8,50 & Mulai Berkembang \\
& Peduli Sosial & 8,83 & Mulai Berkembang \\
& Peduli & 8,83 & Mulai Terlihat \\
\hline Lingkungan & 8,83 & Mulai Berkembang \\
\hline
\end{tabular}

Berdasarkan pada Tabel 16 dapat di-ketahui bahwa ketiga aspek sikap ilmiah pada siklus III pertemuan 1 yaitu kerja keras, disiplin, dan peduli sosial memiliki skor rata-rata dengan kategori mulai berkembang serta peduli lingkungan dalam kategori mulai terlihat. Skor dengan kategori mulai berkem-bang maupun membudaya mencapai $\geq 33$. Selanjutnya, hasil observasi sikap ilmiah siklus III pertemuan 1 dapat dibuat distribusi frekuensi sikap ilmiah siklus III pertemuan 1 yang tertera pada Tabel 17 sebagai berikut:

\section{Tabel 17. Distribusi Frekuensi Sikap IImiah Siklus III Pertemuan 1}

\begin{tabular}{|c|c|c|c|}
\hline \multirow[b]{2}{*}{ Skor } & \multirow{2}{*}{$\begin{array}{c}\text { Frekuensi } \\
\text { (Siswa) }\end{array}$} & \multicolumn{2}{|c|}{ Persentase (\%) } \\
\hline & & Relatif & Kumulatif \\
\hline 27 & 1 & 5,56 & 5,56 \\
\hline 28 & 1 & 5,56 & 11,12 \\
\hline 31 & 1 & 5,56 & 16,68 \\
\hline 32 & 3 & 16,66 & 33,34 \\
\hline 33 & 3 & 16,66 & 50,00 \\
\hline 34 & 1 & 5,56 & 55,56 \\
\hline 37 & 4 & 22,22 & 77,78 \\
\hline 38 & 2 & 11,10 & 88,88 \\
\hline 39 & 1 & 5,56 & 94,44 \\
\hline 40 & 1 & 5,56 & 100,00 \\
\hline Total & 18 & 100 & \\
\hline \multicolumn{4}{|c|}{$\begin{array}{l}\text { Berkembang) } \\
\text { Persentase ketuntasan klasikal 66,67\% } \\
\text { Skor tertinggi } 40\end{array}$} \\
\hline
\end{tabular}

Berdasarkan pada Tabel 17 didapat-kan data mengenai sikap ilmiah siswa siklus III pertemuan 1 yaitu dari 18 siswa, 8 siswa atau $44,45 \%$ dalam kategori membudaya, 4 siswa atau 22,22\% dalam kategori mulai ber-kembang, 4 siswa atau $22,22 \%$ dalam kate-gori mulai terlihat, dan 2 siswa atau 11,11\% dalam kategori belum terlihat. Sehingga dapat dibuat klasifikasi kategori sikap ilmiah siklus III pertemuan 1 pada Tabel 18 berikut: 
Tabel 18. Klasifikasi Kategori Sikap IImiah Siklus III Pertemuan 1

\begin{tabular}{|c|c|c|c|}
\hline $\begin{array}{c}\text { Interval } \\
\text { Skor }\end{array}$ & Kategori & $\begin{array}{c}f \\
\text { (Siswa) }\end{array}$ & $\begin{array}{c}\text { Persentase } \\
(\%)\end{array}$ \\
\hline $27-29$ & $\begin{array}{l}\text { Belum } \\
\text { Terlihat }\end{array}$ & 2 & 11,11 \\
\hline $30-32$ & Mulai Terlihat & 4 & 22,22 \\
\hline $33-35$ & $\begin{array}{c}\text { Mulai } \\
\text { Berkembang }\end{array}$ & 4 & 22,22 \\
\hline $36-38$ & Membudaya & 8 & 44,45 \\
\hline & umlah & 18 & 100 \\
\hline
\end{tabular}

Data sikap ilmiah siklus III pertemuan 1 menunjukkan belum mencapai indikator kinerja yang ditentutak dalam penelitian ini. Kemudian data hasil observasi sikap ilmiah siklus III pertemuan 2 didapatkan skor rata-rata setiap aspek sikap ilmiah siswa siklus III pertemuan 2 yang tertera pada Tabel 19 berikut ini:

Tabel 19. Skor Rata-rata Setiap Aspek Sikap IImiah Siklus III Pertemuan 2

\begin{tabular}{|c|c|c|}
\hline Aspek & $\begin{array}{c}\text { Skor } \\
\text { Rata-rata }\end{array}$ & Kategori \\
\hline Kerja Keras & 9,06 & $\begin{array}{c}\text { Mulai } \\
\text { Berkembana }\end{array}$ \\
\hline $\begin{array}{l}\text { Disiplin } \\
\text { Peduli Sosial }\end{array}$ & $\begin{array}{l}9,22 \\
9,33\end{array}$ & $\begin{array}{l}\text { Membudaya } \\
\text { Membudaya }\end{array}$ \\
\hline $\begin{array}{l}\text { Peduli } \\
\text { Lingkungan }\end{array}$ & 9,06 & $\begin{array}{c}\text { Mulai } \\
\text { Berkembang } \\
\end{array}$ \\
\hline $\begin{array}{l}\text { Jumlah Skor } \\
\text { Rata-rata }\end{array}$ & 36,67 & $\begin{array}{c}\text { Mulai } \\
\text { Berkembang } \\
\end{array}$ \\
\hline
\end{tabular}

Berdasarkan pada Tabel 19 dapat di-ketahui bahwa kedua aspek sikap ilmiah pada siklus III pertemuan 2 yaitu kerja keras, dan peduli lingkungan memiliki skor ratarata dengan kategori mulai berkembang. Kemu-dian kedua aspek yang lain yaitu disiplin dan peduli sosial sudah mencapai kategori mem-budaya Skor kategori mulai berkembang maupun membudaya mencapai $\geq 35$. Selan-jutnya, hasil observasi sikap ilmiah siklus III pertemuan 2 dapat dibuat distribusi frekuensi sikap ilmiah siklus III pertemuan 2 pada Tabel 20 sebagai berikut:

\section{Tabel 20. Distribusi Frekuensi Sikap IImiah Siklus III Pertemuan 2}

\begin{tabular}{cccc}
\hline & Frekuensi & \multicolumn{2}{c}{ Persentase (\%) } \\
\cline { 3 - 4 } Skor & (Siswa) & Relatif & Kumulatif \\
\hline 29 & 1 & 5,56 & 5,56 \\
32 & 1 & 5,55 & 11,11 \\
34 & 1 & 5,55 & 16,66 \\
37 & 10 & 55,56 & 72,22 \\
38 & 2 & 11,11 & 83,33 \\
39 & 1 & 5,56 & 88,89 \\
40 & 2 & 11,11 & 100,00 \\
\hline Total & 18 & 100 \\
\hline Nilai rata-rata kelas 36,67 (Mulai \\
Berkembang) \\
Persentase ketuntasan klasikan 83,33\% \\
Skor tertinggi 40 \\
Skor terendah 29
\end{tabular}

Berdasarkan pada Tabel 20 didapat-kan data mengenai sikap ilmiah siswa siklus III pertemuan 2 yaitu dari 18 siswa, 5 siswa atau $27,78 \%$ dalam kategori membudaya, 10 siswa atau 55,56\% dalam kategori mulai berkembang, 2 siswa atau 
$11,10 \%$ dalam kategori mulai terlihat, dan 1 siswa atau 5,56\% dalam kategori belum terlihat. Sehingga dapat dibuat klasifikasi kategori sikap ilmiah siklus III pertemuan 2 pada Tabel 21 berikut:

Tabel 21. Klasifikasi Kategori Sikap IImiah Siklus III Pertemuan 1

\begin{tabular}{|c|c|c|c|}
\hline $\begin{array}{c}\text { Interval } \\
\text { Skor }\end{array}$ & Kategori & $\begin{array}{c}f \\
\text { (Siswa) }\end{array}$ & $\begin{array}{c}\text { Persentase } \\
(\%)\end{array}$ \\
\hline $29-31$ & $\begin{array}{l}\text { Belum } \\
\text { Terlihat }\end{array}$ & 1 & 5,56 \\
\hline $32-34$ & Mulai Terlihat & 2 & 11,10 \\
\hline $35-37$ & $\begin{array}{c}\text { Mulai } \\
\text { Berkembang }\end{array}$ & 10 & 55,56 \\
\hline $38-40$ & Membudaya & 5 & 27,78 \\
\hline \multicolumn{2}{|c|}{ Jumlah } & 18 & 100 \\
\hline
\end{tabular}

Data sikap ilmiah pada siklus III pertemuan 2 menunjukkan telah mencapai indikator kinerja penelitian yang ditetapkan yaitu $\geq 80 \%$ siswa memiliki sikap ilmiah dengan kategori mulai berkembang maupun membudaya. Oleh karena itu, penggunaan model CTL untuk meningkatkan sikap ilmiah siswa kelas V SD Negeri Mangkubumen Kulon No. 83 Surakarta dapat dinyatakan berhasil diterapkan dan tidak perlu dilan-jutkan ke siklus berikutnya.

Peningkatan persentase ketercapai-an indikator kinerja sikap ilmiah mulai dari pratindakan hingga siklus III pertemuan 2 dapat ditunjukkan dengan tabel perbandingan hasil observasi sikap ilmiah pada Tabel 22 sebagai berikut:

Tabel 22. Perbandingan Hasil Observasi Sikap IImiah

\begin{tabular}{cccccccc}
\hline & \multicolumn{3}{c}{$\begin{array}{c}\text { Frekuensi } \\
\text { Ket. }\end{array}$} & $\begin{array}{c}\text { Sikap IImiah } \\
\text { (siswa) }\end{array}$ & \multicolumn{2}{c}{$\begin{array}{c}\text { Ketercapai- } \\
\text { an Indikator } \\
\text { Kinerja }\end{array}$} & $\begin{array}{c}\text { Skor } \\
\text { Rata- } \\
\text { rata }\end{array}$ \\
\cline { 2 - 6 } & D & C & B & A & f & $\%$ & \\
\hline PT & 3 & 5 & 6 & 4 & 10 & 55,56 & 35,05 \\
S I P1 & 2 & 6 & 4 & 6 & 10 & 55,56 & 21,27 \\
S I P 2 & 1 & 5 & 7 & 5 & 12 & 66,67 & 23,50 \\
S II P 1 & 1 & 9 & 3 & 5 & 8 & 44,44 & 23,94 \\
S II P 2 & 3 & 6 & 4 & 5 & 9 & 50,00 & 29,05 \\
S III P 1 & 2 & 4 & 4 & 8 & 12 & 66,67 & 34,33 \\
S III P 2 & 1 & 2 & 1 & 5 & 15 & 83,33 & 36,67 \\
\hline
\end{tabular}

Berdasarkan pads Tabel 22 tersebut, data mengenai perbandingan hasil observasi sikap ilmiah mulai dari pratindakan hingga siklus III pertemuan 2 juga dapat disajikan dala bentuk grafik pada Gambar 1 sebagai berikut: 


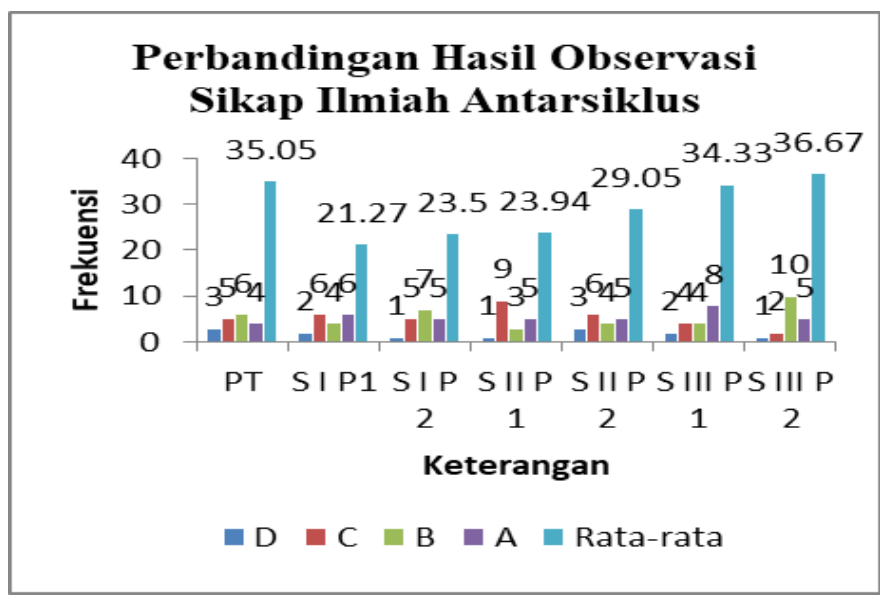

\section{Gambar 1. Perbandingan Hasil Sikap IImiah Antarsiklus}

Peningkatan yang terjadi pada sikap ilmiah siswa tidak hanya dilihat dari ketercapaian indikator kinerja penelitian, tetapi ju-ga rata-rata sikap ilmiah dikelas $\mathrm{V}$ dan peningkatan sikap ilmiah pada setiap siswa dari kategori belum terlihat hingga membudaya. Nurhadi dalam Baharuddin dan Wahyuni (2015: 190-191) menjelaskan bahwa Pembelajaran Kontekstual (Contextual Teaching and Learning) merupakan konsep belajar yang dapat membantu guru me-ngaitkan antara materi yang diajarkannya dengan situasi dunia nyata siswa dan men-dorong siswa membuat hubungan antara pengetahuan yang dimilikinya dengan pene-rapannya dalam kehidupan mereka seharihari. Konsep ini bertujuan agar hasil pembe-lajaran yang diperoleh dapat lebih bermakna bagi siswa karena proses pembelajaran da-pat berlangsung secara alamiah dalam ben-tuk kegiatan siswa bekerja dan mengalami, bukan transfer pengetahuan dari guru ke sis-wa. Aktivitas yang dilakukan siswa melalui kegiatan percobaan dan pengamatan mam-pu mendukung pengembangan sikap ilmiah siswa. Didukung dengan pendapat Fatonah \& Prasetyo (2014: 36) yang menyatakan bahwa pembelajaran kontekstual dapat me-motivasi siswa membuat hubungan antara pengetahuan dan penerapannya dalam kehi-dupan mereka sebagai anggota keluarga, warga negara, dan tenaga kerja. Sehingga mampu meningkatkan sikap ilmiah siswa dan mampu menerapkannya dalam kehidu-pan sehari-hari baik dalam lingkungan keluarga, sekolah, maupun bermasyarakat. Ber-dasarkan pada hasil penelitian yang telah diuraikan, membuktikan bahwa penggunaan model Contextual Teaching and Learning (CTL) dapat meningkatkan sikap ilmiah sis-wa kelas V SD Negeri Mangkubumen Kulon No. 83 Surakarta tahun ajaran 2017/2018.

\section{SIMPULAN}

Berdasarkan pada hasil penelitian tindakan kelas yang telah peneliti laksanakan sebanyak tiga siklus dengan masing-masing siklus terdiri atas dua kali pertemuan dengan menggunakan model Contextual Teaching and Learning (CTL) pada pembelajaran IPA di kelas V SD Negeri Mangku-bumen Kulon No. 83 Surakarta, dapat disimpulkan bahwa penggunaan model CTL pada pembelajaran IPA dapat meningkatkan sikap ilmiah siswa kelas V SD Negeri Mangku-bumen Kulon No. 83 Surakarta tahun ajaran 2017/2018. Hal ini ditunjukkan dengan data hasil observasi sikap ilmiah siswa pada aspek kerja keras, disiplin, peduli sosial, dan peduli lingkungan yang menyebutkan bahwa keempat sikap memiliki nilai dengan kategori mulai berkembang (B) dan membudaya (A). Persentase ketercapaian kinerja penelitian pada pratindakan sebesar $55,56 \%$ atau se-banyak 10 siswa. Hal ini tidak mengalami ke-naikan maupun penurunan pada siklus I per-temuan 1. Kemudian pada siklus I perte-muan 2 mengalami peningkatan menjadi $66,67 \%$ atau 12 siswa. Pada siklus II per-temuan 1 mengalami penurunan menjadi 44,44\% atau 8 siswa dan meningkat pada pertemuan 2 
sebesar $50,00 \%$ atau 9 siswa. Pada siklus III pertemuan 1 meningkat lagi menjadi $66,67 \%$ atau sebanyak 12 siswa. Kemudian, meningkat kembali pada siklus III pertemuan 2 menjadi sebesar 83,33\% atau 15 siswa yang memiliki sikap ilmiah dengan kategori mulai berkembang maupun mem-budaya.

\section{DAFTAR PUSTAKA}

BSNP. (2006). Permendikbud Nomor 22 Tahun 2006 Tentang Standar Isi Nasional Pendidikan. Jakarta: Kementerian Pendidikan Nasional. Diperoleh 23 Januari 2018 diakses pada http://bsnp-indonesia.org/id/wp-content/uploads/isi/SD-MI.zip Baharuddin \& Wahyuni, E. N. (2015). Teori Belajar dan Pembelajaran. Yogyakarta: ArRuzz Media.

Bundu, P. (2006). Penilaian Keterampilan Proses dan Sikap IImiah dalam Pembelajaran Sains Sekolah Dasar. Jakarta: Direktorat Jenderal Pendidikan Tinggi Direktorat Ketenagakerjaan.

Fatonah, S \& Prasetyo, Z.K. 2014. Pembelajaran SAINS. Yogyakarta: Penerbit Ombak Iskandar. (2009). Penelitian Tindakan Kelas. Jakarta: Gaung Persada (GP) Press.

Samatowa, U. (2010). Pembelajaran IPA di Sekolah Dasa. Jakarta: PT. Indeks

Susanto, A. (2013). Teori Belajar dan Pembelajaran di Sekolah Dasar. Jakarta: Prenamedia Group. 